\title{
Angiotensin converting enzyme inhibitors and diabetic nephropathy
}

\author{
Their effects on proteinuria may be independent of their effects on blood pressure
}

In this issue Björck and colleagues report that treatment with the angiotensin converting enzyme inhibitor enalapril delays the progression of overt diabetic nephropathy (p 339). ${ }^{1}$ This continues a series of papers on this topic begun in the $B M \mathcal{F}$ a decade ago. ${ }^{2-12}$

Retrospective studies of patients with insulin dependent diabetes and albuminuria have previously suggested that antihypertensive treatment, usually with $\beta$ blockers and diuretics, improves survival. ${ }^{10} 13$ If long term prospective studies confirm this finding then postponing end stage renal failure, which currently costs the United States about $\$ 5400 \mathrm{~m}$ a year, ${ }^{14}$ may be within reach.

In diabetic patients the process that starts with glomerular hyperfiltration takes on average 30 years to progress through microalbuminuria and proteinuria to end stage renal failure. ${ }^{15}$ Trials of intervention therefore require end points other than end stage renal failure, a point that was accepted by a meeting of doctors, regulatory agencies, and drug companies organised by the Food and Drug Administration last year. A fall in glomerular filtration rate was accepted as a satisfactory end point, provided it was measured for more than two to three years (with longer follow up preferable). Reducing the rate of fall of the glomerular filtration rate is likely to postpone end stage renal failure. Microalbuminuria (between $20-200 \mu \mathrm{g} / \mathrm{min}$ ) was also accepted as a surrogate end point in trials lasting more than a few years as stabilisation or reduction of albuminuria or microalbuminuria seems to be associated with preservation of the glomerular filtration rate. ${ }^{15} 16$

In their study Björck and colleagues compared enalapril and metoprolol (both given with frusemide) in patients with diabetic nephropathy. ${ }^{1}$ The rate of fall in the glomerular filtration rate was significantly lower in patients treated with enalapril $(2.0 \mathrm{ml} / \mathrm{min} /$ year $)$ than in patients treated with metoprolol $(5.6 \mathrm{ml} / \mathrm{min} /$ year $)$. Mean arterial blood pressure hardly varied between the two groups. In the patients treated with enalapril the glomerular filtration rate remained virtually constant after six months of treatment. Over the course of the study patients given enalapril experienced a fall in the glomerular filtration rate not very different from the physiological reduction that occurs in middle age $(1 \mathrm{ml} / \mathrm{min} /$ year $) .{ }^{17}$ By contrast, in diabetic patients with albuminuria who have not been treated with antihypertensive drugs the glomerular filtration rate falls at a rate of about $10 \mathrm{ml} / \mathrm{min} /$ year. ${ }^{2 \mathrm{~s}}$

To know whether intervention would help postpone the development of end stage renal failure longer follow up would obviously be needed. The results of treating patients with near normal glomerular filtration rates, normoalbuminuria, or early microalbuminuria would also be interesting: inhibition or reversal of microalbuminuria with treatment has not yet been shown. The findings of Björck et al are at some variance with those of other researchers: for example, Parving et al reported that after 10 years' treatment with metoprolol and diuretics the glomerular filtration rate fell by only $1 \cdot 25 \mathrm{ml} / \mathrm{min} /$ year. ${ }^{18}$ Grönhagen-Riska found that the two treatments compared by Björck et al produced similar rates of fall in the glomerular filtration rate. ${ }^{19}$

Whether very early intervention works was tested in a prospective trial by Mathiesen et al. ${ }^{16}$ In normotensive patients with incipient diabetic nephropathy (urinary albumin excretion rate $20-200 \mu \mathrm{g} / \mathrm{min}$ ) four years' treatment with captopril (and a thiazide diuretic for the last 18 months) prevented the development of proteinuria (urinary albumin excretion rate $>200 \mu \mathrm{g} / \mathrm{min}$ ). Seven out of 23 untreated patients with microalbuminuria developed proteinuria during the four year trial compared with none of the 21 patients treated with captopril. Importantly, in the seven patients who developed proteinuria the glomerular filtration rate fell, whereas in those control patients who did not develop proteinuria it remained stable. Without intervention the glomerular filtration rate falls late in the microalbuminuric stage.

In the study by Mathiesen et al patients with albumin excretions of $70-200 \mu \mathrm{g} / \mathrm{min}$ seemed to benefit most from treatment with an angiotensin converting enzyme inhibitor. ${ }^{16}$ Whether this effect is independent of the change in blood pressure is disputed; albuminuria may be a better marker for disease severity than blood pressure in this situation. Larger, blinded studies would be needed to decide this point.

Angiotensin converting enzyme inhibitors seem to work at several stages in the development of diabetic renal disease-normoalbuminuria, microalbuminuria, and overt nephropathy - and to have several different actions. These include effects on systemic hypertension, ${ }^{20}$ renal haemodynamics, ${ }^{2021}$ the glomerular membrane, ${ }^{22}$ and possibly the growth characteristics of glomerular tissues, which may be relevant to the pathogenesis of renal disease..$^{23} 24$

A few problems may, however, arise with use of angiotensin converting enzyme inhibitors. Because they may increase serum potassium concentration this should be monitored and their use combined with potassium losing diuretics. 
Because blood pressure may fall precipitately early in treatment, starting with a small dose is advisable. The glomerular filtration rate may fall acutely during the first weeks and months of treatment, an effect that is exacerbated by overt nephropathy. Large doses may be needed to affect incipient diabetic nephropathy, ${ }^{16}$ which may cause problems in the presence of renal artery stenosis (albeit this is not particularly common in diabetic nephropathy). Antihypertensive treatment does not consistently reduce the fall in glomerular filtration rate, especially in patients with very poorly controlled diabetes who have severe hypertension, obesity, or hyperlipidaemia.

To date, long term intervention studies (with self controlled design) have been reported only in proteinuric patients with insulin dependent diabetes. ${ }^{25} 1825$ Patients with noninsulin dependent diabetes and albuminuria warrant study: they make up a large proportion of those patients who develop end stage renal failure. Short term studies suggest that angiotensin converting enzyme inhibition may also be useful in patients with non-diabetic renal disease: Apperloo and colleagues recently reported that enalapril significantly reduced albuminuria in such patients. ${ }^{26}$ If longer studies confirm that angiotensin converting enzyme inhibitors have proteinuria lowering effects, independent of their effects on blood pressure, then whether their prophylactic use preserves the glomerular filtration rate in diabetic and non-diabetic patients with nephropathy should be tested.

CARL ERIK MOGENSEN

Professor of Medicine,

Medical Department $M$ (Endocrinology and Diabetes),

Kommunehospitalet, University Hospitals in Aarhus,

DK-8000 Aarhus C, Denmark

\footnotetext{
Björck S, Mulec H, Johnsen SA, Nordén G, Aurell M. Renal protective effect of enalapril in diabetic nephropathy. BMJ 1992;304:339-43.

Mogensen CE. Long-term antihypertensive treatment inhibiting progression of diabetic nephropathy. $B M 7$ 1982;285:685-9.
}

3 Björck S, Nyberg G, Mulec H, Granerus G, Herlitz H, Aurell M. Beneficial effects of angiotensin (n) 1986;293:471-4.

4 Hommell E, Parving H-H, Mathiesen E, Edsberg B, Nielsen MD, Giese J. Effect of captopril on kidney function in insulin-dependent diabetic patients with nephropathy. BMJ 1986;293:467-70.

5 Parving H-H, Andersen AR, Smidt UM, Hommel E, Mathiesen ER, Svendsen PA. Effect of antihypertensive treatment on kidney function in diabetic nephropathy. BMF 1987;294:1443-7.

6 Marre M, Leblanc II, Suarez L, Guyenne T-T, Ménard J, Passa Ph. Converting enzyme inhibitio and kidney function in normotensive diabetic patients with persistent microalbuminuria. $B M \mathcal{T}$ 1987;294:1448-52.

7 Parving H-H, Hommel E, Smidt UM. Protection of kidney function and decrease in albuminuria by captopril in insulin dependent diabetics with nephropathy. BMJ 1988;297:1086-91.

8 Marre M, Chatellier G, Leblanc H, Guyene TT, Ménard J, Passa P. Prevention of diaberic nephropathy with enalapril in normotensive diabetics with microalbuminuria. $B M \mathcal{F}$ 1988;297:1092-5.

9 Parving H-H, Hommel E, Nielsen MD, Giese J. Effect of captopril on blood pressure and kidney function in normotensive insulin dependent diabetics with nephropathy. $B M 7$ 1989;299:533-6. Parving H-H, Hommel E. Prognosis in diabetic nephropathy. BMI 1989;299:230-3.

11 Björck S, Mulec $\mathrm{H}$, Johnsen SA, Nyberg G, Aurell M. Contrasting effects of enalapril and metoprolol on proteinuria in diabetic nephropathy. BMF 1990;300:904-7.

12 Melbourne Diabetic Nephropathy Study Group. Comparison between perindopril and nifedipine in hypertensive and normotensive diabetic patients with microalbuminuria. $B M$ 1991;302:210-6.

13 Mathiesen ER, Borch-Johnsen K, Jensen DV, Deckert T. Improved survival in patients with diabetic nephropathy. Diabetologia 1989;32:884-6.

14 Striker GE, Agodoa LL, Held P, Doi T, Conti F, Striker LJ. Kidney diasease of diabetes mellitus (diabetic nephropathy): perspectives in the United States. F Diabetic Complications 1991;5:51-2.

15 Mogensen CE. Pharmacology of the kidney in IDDM patients. In: Mogensen CE, Standl E, eds. Pharmacology of diabetes. Present practice and future perspectives. Berlin, New York: Walter de Gruyter 1991:263-81. (Diabetes Forum Series vol 3.)

16 Mathiesen ER, Hommel E, Giese J, Parving H-H. Efficacy of captopril in postponing nephropathy in normotensive insulin dependent diabetic patients with microalbuminuria. $B M J$ 1991;303:81-7.

17 Slack TK, Wilson DM. Normal renal function. CIN and CPAH in healthy donors before and after nephrectomy. Mayo Clin Proc 1976;51:296-300.

18 Parving H-H, Smidt UM, Mathiesen ER, Hommel E. Ten years' experiences with antihypertensive treatment in diabetic nephropathy. Diabetologia 1991;34(suppl 2):A38.

19 Grönhagen-Riska C, Honkanen E, Metsärinne K, Rosenlöf K, Tikkanen I, Fyhrquist F. ACE inhibition versus conventional antihypertensive treatment $(B$ blockade) in diabetic nephropathy. Am $\mathcal{F}$ Hypertens 1990;3:67A.

20 Mogensen CE, Hansen KW, Mau Pedersen M, Christensen CK. Renal factors influencing blood pressure threshold and choice of treatment for hypertension in IDDM. Diabetes Car 1991;14(suppl 4):13-26.

21 Pedersen MM, Schmitz A, Pedersen EB, Danielsen H, Christiansen JS. Acute and long-term renal effects of angiotensin converting enzyme-inhibition in normotensive, normoalbuminuric insulindependent diabetic patients. Diabetic Med 1988;5:562-9.

22 Morelli E, Loon N, Meyer T, Peters W, Myers BD. Effects of converting-enzyme inhibition on barrier function in diabetic glomerulopathy. Diabetes 1990;39:76-82.

23 Ichikawa I, Ikoma M, Fogo A. Glomerular growth promoters, the common key mediator for progressive glomerular sclerosis in chronic renal disease. Adv Nephrol 1991;20:127-48.

24 Flyvbierg A Frystyk J, Sillesen IB, Orskov $H$. Growth hormone and insulin-like growth factor I in experimental and human diaberes. In: Alberti KGMM Krall LP, eds. The diabetes annuall6. Elsevier: Science Publishers, 1991:562-90.

25 Louis TA, Lavori PW, Bailar JC III, Polansky M. Crossover and self-controlled designs in clinical reseat N Engl $r$ Med 1984,310:24-31.

26 Apperloo AJ, de Zeeuw D, Sluiter HE, de Jong PE. Differential effects of enalapril and atenolol on proteinuria and renal haemodynamics in non-diabetic renal disease. BMJ 1991;303:821-4.

\section{Paying for health services}

\section{All change}

Health care reform is in fashion internationally. ${ }^{1}$ Those countries that have relied on a large measure of private finance and the use of market mechanisms, most notably the United States, are searching for ways of achieving more comprehensive coverage and cost control. Equally, those countries that have based their health care systems mainly on public finance and planning mechanisms - for example, the United Kingdom and Sweden - are showing interest in competition as a means of increasing efficiency and enhancing responsiveness to consumers. Even the pluralistic systems of western Europe have not escaped reform, with countries as varied as France, Germany, and the Netherlands all seeking to tackle deep seated problems in financing and delivering health care.

Of all these countries the United States faces the greatest challenges. With expenditure rapidly approaching $12 \%$ of its gross domestic product and with over 30 million Americans uninsured, policy makers have long puzzled about how they could introduce reforms to achieve a better balance between equity, access, comprehensiveness, efficiency, and cost containment. Individual states have taken the initiative in addressing some of these issues - for example, Oregon and its attempt to set more explicit priorities for the use of Medicaid funds for the poor ${ }^{2}-$ but so far there has been no concerted attempt to promote change at the federal level.

Against this background a new study of health insurance in different countries offers a timely analysis of the direction that reform might take. ${ }^{3}$ As the study seeks to emphasise, those endeavouring to change the American "non-system" do not have to embrace the fully blown national health services that exist in the United Kingdom and several other countries. One alternative would be to move towards the social insurance funding system adopted in western Europe. Using evidence from France, Germany, Belgium, the Netherlands, and Switzerland, the study brings together a huge amount of information to show what this might mean for the United States.

Although the author argues that his book "is not a plea on behalf of statutory health insurance," there is no disguising his preference for this method of funding compared with the diverse arrangements that currently exist in the United States. As he shows, social insurance systems began in the late 